\title{
CAUSALITY OF RISKS, COST OF EQUITY AND SHADING OF THE ENTERPRISE INCOME
}

\author{
Oleh Tereshchenko', Nataliia Babiak ${ }^{2}$
}

\begin{abstract}
The scandals with concealment of income by large companies in tax havens, the unresolved problem of estimating the size of the shadow economy, and its high share in emerging markets (EM) make issues of the methodology for calculating the shadow income of enterprises relevant for today. The aim of the study is to substantiate the method for calculating the scope of shadowing of legal business income based on the method of shadow rates of costs on invested (equity) capital. The authors construct a two-factor linear regression, which enables to test the hypothesis of the effect of the expected rate of return and return on equity at the shadow economy level. The regression analysis confirms a negative correlation between ROE and the shadow economy level. There is a positive correlation between the risks of investing in equity, which are reflected in the expected rate of return on capital, and the total income shadowing. The regression-correlation analysis of the dependence of the shadow income of enterprises on these factors confirms a similar pattern. Comparison of the obtained values of the shadow income of enterprises in Ukraine with alternative estimates of the shadow economy reveals a higher sensitivity of the proposed method to changes in country risks, as well as to decisions aimed at improving business conditions. It is confirmed that the exacerbation of risks automatically reflects on the expectations regarding the return on investment and on the official declaration of income. Therefore, the shadow economy reduction is related directly to a set of measures aimed at minimizing the risks of business activities.
\end{abstract}

Key words: shadow income, cost of equity, shadow rate of cost of equity, risk premium, interest rates, return on equity.

JEL Classification: D24, D81, E26

\section{Introduction}

Thehigh-profilescandals surroundingthe concealment of enterprises and their owners' incomes are a constant challenge for researchers of the shadow economy issues. For example, the so-called Panama Papers or the largescale tax evasion of a number of well-known companies in the world (Halliburton, Netflix, IBM, Delta Air Lines, Chevron, General Motors). In 2018, 60 Fortune 500 companies were not subject to corporate taxation, with a total revenue of approximately 80 billion USD. Quite eloquent is the situation with Amazon, which has generated 10 billion USD income, and then claimed tax rebate (Gardner, Wamhoff, Martellotta \& Roque, 2019). Nine out of ten global companies own at least one subsidiary registered in tax havens. Developing countries lose 100 billion USD annually as a result of tax evasion in the USA (Oxfam Deutschland, 2019). According to J. E. Stiglitz and M. Pieth (2016), tax havens contribute to the development of the shadow

\footnotetext{
Corresponding author:

${ }^{1}$ Vadym Hetman Kyiv National Economic University, Ukraine.

E-mail: corfinua@ukr.net

ORCID: https://orcid.org/0000-0001-8808-1383

${ }^{2}$ Vadym Hetman Kyiv National Economic University, Ukraine.

E-mail: nataliia.babiak@kneu.edu.ua

ORCID: https://orcid.org/0000-0002-3210-4045
}

side of globalization. Therefore, the world community has the right to recognize them as evil that must be overcome.

Income shadowing is a result of not only the high level of taxation or over-regulation of the economy. Shadowing drivers also include psychological and mental factors, macro- and microeconomic risks, and a corruption component. Due to the specificity of factors that influence the growth (or decrease) of a particular component of shadow activity, it is heterogeneous in composition and structure across countries and groups of countries. In most developed countries, shadow activity is associated with illegal employment, respectively, with the shadow wages that entail tax and social payments avoidance. In EM countries, the main forms of its manifestation are the concealment of items subject to taxation by enterprises, the circumvention of official rules on capital movements and currency regulation. 
The development of tools for minimizing the informal sector requires to clearly identify the components of the shadow economy, their scopes and causes. According to established views, shadow business creates additional risks that affect the cost of equity of enterprises towards its growth. The proposed study presents a number of alternative hypotheses regarding the causality of the cost of investment capital and the risks of the shadow economy. The study presents a number of alternative hypotheses regarding the causality of the price of investment capital and the risks of the shadow economy. The article reveals that the complex of local risks of business activities leads, on the one hand, to an increase in the cost of raising capital and on the other hand, to the need for withdrawal of income and the shadow sector. The complex chain of reasons explains the escape into the shadows as a means of reducing the risks of business. According to empirical data, in times of recession and crisis, growing uncertainty leads to an increase in the shadow activity. In the presence of causal links between the shadow activity of enterprises and the cost of equity, the latter should be considered as a variable to calculate the scope of undeclared income of enterprises as the largest segment of the shadow economy. In the article, the level of enterprise income shadowing on the basis of the expected income for investment in the equity is estimated in the context of Ukraine.

\section{Previous research review}

In the study of the informal economy in developed countries, the main emphasis is on the issues of tax evasion by large corporations and undeclared income from shadow employment. For example, F. Schneider and B. Boockmann (2018) distinguish legal and illegal activities, monetary and non-monetary transactions in the shadow economy. Undeclared business income, hidden assets, and employee salaries are all assessed in one unit. However, the nature of individual types of shadow activity is different. A unified approach to their estimation leads to a high probability of error, since the question remains about the final evaluation object. The need for a differentiated estimation of individual components of the shadow economy, in particular, undeclared incomes of enterprises and employees is explained both by the different nature of their occurrence and by the different instruments of minimization. For example, T. Putnins and A. Sauka (2015) apply such structuring in the process of estimating the size of the informal sector in the Baltic countries.

Depending on the interpretation of the shadow economy components, a number of direct and indirect methods are used to estimate its size, but they are not flawless. Direct methods relate to statistical surveys of business representatives and the detection of shadow transactions at enterprises. For example, T. Putnins and A. Sauka use surveys of company responsible executives and managers to estimate the size of the shadow economy. From their perspective, the total shadow economy is estimated by components as follows: undeclared corporate incomes, unregistered workers, and undeclared wages. Due to the possible respondents' manipulation, the survey method is characterized by a high level of subjectivity. Its data and objectivity are rather ambiguous.

Given the variety of schemes and forms of shadowing the cost of equity, as well as the extreme cost of control, it is unrealistic mission to determine the actual cost of equity by direct methods. The analysis of detecting undeclared incomes is time-consuming and selective. The complexity of studying the processes in the shadow economy is related to the lack of empirical data. For any business, the shadow activity is the most secret information that is accessible to a very limited number of people. The facts of shadow transactions are rare and information about them is unsystematic and statistically irrelevant. That is why most of the shadow economy valuations are focused on the analysis of cause and effect factors and the estimation of the shadow activity by indirect methods.

Indirect methods are based on the comparison of household income and expenditure, the analysis of individual macroeconomic and monetary indicators, the study of the causal relationships between technological indicators and GDP, and so on. The most well-known indirect way of estimating the size of the shadow economy is the MIMIC (Multiple Indicators Multiple Causes) method, which is based on the analysis of multiple impact factors and multiple indicators of the size of the shadow economy. In 2018, the IMF published the results of a study by L. Medina and F. Schneider (2018) that used MIMIS to estimate the shadow economy in 158 countries over the period of 1991-2015. Multiple impact factors included variables as follows: trade openness index, GDP per capita, unemployment rate, government scale and stability indices, fiscal freedom and rule of law indicators, level of corruption control. In addition, the following indicators were used: the level of the economically active population, the currency's stability and the per capita GDP growth. According to T. Breusch (2005), the bottleneck of the method is the doubtful notion that only the size of the shadow economy can be regarded as a latent change that co-integrates causal variables and indicators. In addition, the results of the evaluation are too sensitive to the units in which the variables are measured. Another drawback of the approach is its lack of sensitivity to current country risks.

Given the issues of structuring and estimating the shadow economy, this study focuses on developing a fundamentally new approach to estimating the largest component of the shadow economy that is the size of incomes undeclared by enterprises. According to our hypothesis, the total annual incomes that "flow" into the shadow sector is equal to the amount of hidden (implicit) costs of capital. The largest share of the 
shadow economy's income is generated through the concealment of equity costs. The cost of equity for companies operating on EM is largely implicit (hidden or shadow). It is about undeclared incomes that are either incomplete or missing in the official reporting. The scientific task is to justify the instruments for estimating the amount of the cost of capital output in the shadow sector, as well as to develop recommendations on the anti-shadowing of capital expenditures.

The aim of the study is to substantiate the method of calculating the shadowing of legal business income on the basis of the method of the shadow cost rate of invested (equity) capital.

\section{Results and discussion}

The proposed approach to the calculation of the size of shadow income is based on determining the expectations of economic entities on the return on investment and their motivation for shadow transactions. This requires structuring the components of the shadow economy and examine them at the angle of the classic risk/return ratio. The size of the shadow economy and the amount of output of the shadow sector directly depend on the set of macro and microeconomic risks that accompany the financial and economic activities of enterprises. The risk indicator of investing in an asset is the interest rate at which equity is invested. Interest rates reflect employment and wages, prices, investment and business activity. High local risks lead to a high expected market risk premium that cannot be realized by fully operating within the formal sector. The consequence of this is the shadowing of the cost of capital (above all equity).

A specificity of financing a business in developing markets is equity raising on non-market terms. In the context of this study, non-market terms for raising capital arise in the case of shadow cost of equity resulting from a discrepancy between the official capital charge and the actual costs. The shadow cost of equity is transformed into revenues of the shadow economy and generate the vast majority. The transfer of the cost of equity to the shadow sector is primarily related to tax evasion, which in one way or another violates the market terms for raising and servicing capital. In countries with a distorted financial market, there are well-established schemes for transferring cost of equity to the shadow sector. For these purposes, big business primarily uses offshore zones, and small business uses private entrepreneurs, various forms of providing bogus services or making bogus costs.

The proposed approach to estimating the size of the shadow sector requires utilising information on the total official payments within the framework of the cost of equity in terms of its individual categories and the rate of return expected by capitalists. The source of the official cost of equity is reported net income, and the channels of remuneration are dividends and gains in the market value of corporate rights. The latter is the result of income hoarding and increase in market value of the enterprise. Therefore, the cost of equity, recorded in the financial statements, will be consistent with the return on equity invested in the enterprise.

According to our hypothesis, the size of the shadow cost of equity (the additional shadow interest rate) corresponds to the difference between the rate determined by indirect methods and cost of capital officially reported. The latter correspond to the officially declared net profit of the enterprise. Other assumptions underlying the study are as follows:

- shadowing of the enterprise's income is carried out with the knowledge of its key shareholders;

- undeclared corporate income is almost entirely used as a payment to the shareholders for equity;

- enterprises generate value using legally invested capital;

- economic agents have no incentive to manipulate the value of assets and the amount of invested capital;

- the total amount of official and the shadow cost of equity correspond to the expected market interest rate, which is determined by one of the CAPM modifications for developing markets.

We assume that income shadowing is a business response to the additional risks and threats to it. The shadow economy component of income shadowing is suggested to be determined on the basis of the transformation of the shadow rate of cost of equity into the absolute amount of undeclared income. The shadow rate of cost of equity is calculated as the difference between the expected market rate of cost of equity and the return on equity invested that is determined according to official reporting.

It is of importance to ground the key parameters of the model of calculating the expected cost of equity capital totally in the corporate sector of the economy. According to the well-known CAPM model, investors' expected rate of return on investment depends on the risk-free rate of return, the average rate of return on the capital market and the systematic risk of investing in a specific asset. Given calculating model parameters for underdeveloped countries, additional difficulties arise due to the lack of a credible database, the high volatility of the local stock market or its illiquidity, legal and macroeconomic uncertainty, and a number of other circumstances. Under these factors, an average EM enterprise, for example in Ukraine, is at greater risk than a similar enterprise operating in developed markets. According to CAPM, these additional risks are diversified and therefore, they are non-systematic and do not affect the valuation of investments and assets. From a theoretical point of view, it is appropriate to consider diversified risks in the monetary flow forecasting process (Copeland, Koller \& Murrin, 2000). For non-systematic risks, the market does not pay an additional risk premium. In this case, the allowance 
(or discount) for the additional risk premium should not be considered as the relevant risks are properly taken into account in determining the beta and market risk premium (MRP). However, theoretically perfect CAPM is based on far-fetched assumptions (Tereshenko, Voloshanyk \& Savchuk, 2019). In practice, an approach, which takes at least some of the diversified risks into the rate of cost of equity, is applied.

Considering the neoclassical CAPM and A. Damodaran's recommendations regarding the need to take into account specific local risks (country risks), the expected market rate of cost of equity (Rem) includes risk-free rate of return $\left(r f_{g}\right)$, global market risk premium (MRg), beta factor and country risk premium (CRP). The proposed model for calculating the average expected market rate of cost of equity is as follows:

$$
R_{e m}=r f_{g}+\mathrm{MRP}_{\mathrm{g}}+\mathrm{CRP}
$$

Given the impossibility to calculate objectively the risk-free rate of return and the lack of credible information from the local stock market, Ukraine should accept a global risk-free rate, a global risk premium and minimization of domestic stock market data as an information base. Model 1 does not contain a beta factor, as it aims to calculate the average market rate of return that corresponds to a beta factor at the unit level. Therefore, this factor cannot be taken into account in the calculations.

Table 1 shows the calculations of the expected market return on equity investments of Ukrainian enterprises. The results from the application of model (1) are expressed in USD. In order to translate the expected rate of return into the local national currency, the value of inflation in Ukraine and the USA for the respective years should be adjusted. The well-known I. Fisher algorithm is used to describe the relationship between inflation rate, nominal and real interest rates.

In reality, the impact of factors behind the growth (or decrease) of the shadow economy manifests itself over a certain period. We assume that some businesses respond to risk factors during the period of their manifestation and immediately transform their income into a shadow, using the existing shadow economy infrastructure. However, a number of economic agents can act ahead of the curve by shifting their earnings into the shadows, projecting exacerbations of risk factors. Other entities, on the contrary, need time to become aware of the risk factors involved and to develop revenue-minimizing shadow schemes. If, as a result of risk exacerbation, the market expects an abnormally high shadow rate of return for a certain period, it does not mean that it will be realized by all entities during that period. Temporal displacement can occur both before and after the occurrence of factors (risks). The situation is the same in case of risk improvement. Businesses do not immediately take income from the shadows in response to government decisions aimed at reducing risk and reducing taxation. Therefore, the estimation of the shadow economy level requires the utilization of the smoothed time-series values of the expected risk premium. The simplest algorithm for averaging time series values is used for smoothing. As the data averaging interval is of three periods, the calculations do not show smoothed figures for 2008-2009.

The results of the calculation of the paired correlation coefficients revealed that among the numerous factors influencing the size of the shadow economy, it is advisable to choose the two most representative: the expected market return (Rem) and return on equity (ROE). Table 2 shows the basic information to construct a two-factor regression, which will test the hypothesis of the influence of these factors and the level of the shadow economy.

Evidently, the expected rate of return on equity and the income of the shadow sector are rising in line with the rising risks and the CRP parameter mentioned above. High risks lead to a decrease in income officially reported. The average return on equity of the Ukrainian enterprises during the period under analysis was negative or was at a minimal positive level. The less country's risk premium is the less shadow interest rate

Table 1

The calculation of the expected market return on equity investments of enterprises in Ukraine, 2008-2018

\begin{tabular}{|c|c|c|c|c|c|c|c|c|}
\hline Year & RfR & CRP & $\begin{array}{c}\text { Equity Risk } \\
\text { Premium }\end{array}$ & $\begin{array}{c}\text { Expected } \\
\text { market return } \\
\text { (Rem), USD }\end{array}$ & $\begin{array}{c}\text { Inflation rate, } \\
\text { US }\end{array}$ & $\begin{array}{c}\text { Inflation rate, } \\
\text { UA }\end{array}$ & $\begin{array}{c}\text { Expected } \\
\text { market } \\
\text { return, UA }\end{array}$ & $\begin{array}{c}\text { Expected market } \\
\text { return, } \\
\text { UAmoothed) }\end{array}$ \\
\hline 2008 & 2.2 & 5.25 & 10.04 & 12.24 & 103.84 & 125.23 & 35.4 & $* *$ \\
\hline 2009 & 4.04 & 9.75 & 14.75 & 18.79 & -100.36 & 115.9 & 38.2 & $* *$ \\
\hline 2010 & 3.3 & 8.25 & 12.75 & 16.05 & 101.6 & 109.4 & 25.0 & 32.8 \\
\hline 2011 & 1.9 & 7.5 & 12.5 & 14.4 & 103.2 & 108 & 19.7 & 27.6 \\
\hline 2012 & 1.8 & 7.5 & 13.5 & 15.3 & 102.1 & 100.6 & 13.6 & 19.4 \\
\hline 2013 & 2.9 & 9 & 14.8 & 17.7 & 101.46 & -100.2 & 15.8 & 16.4 \\
\hline 2014 & 2.2 & 11.25 & 16.25 & 18.45 & 101.62 & 112.1 & 30.7 & 20.0 \\
\hline 2015 & 2.3 & 15 & 20.75 & 23.05 & 100.12 & 148.7 & 82.8 & 43.1 \\
\hline 2016 & 2.4 & 14.9 & 20.9 & 23.3 & 101.26 & 113.9 & 38.7 & 50.7 \\
\hline 2017 & 2.4 & 14.21 & 19.9 & 22.3 & 102.13 & 114.4 & 37.0 & 52.8 \\
\hline 2018 & 2.7 & 10.38 & 15.46 & 18.16 & 102.44 & 110.9 & 27.9 & 34.5 \\
\hline
\end{tabular}


Vol. 6, No. 2, 2020

Baltic Journal of Economic Studies

Table 2

The calculation of factors of the influence on the level of the size of the shadow economy in Ukraine, 2010-2018

\begin{tabular}{|c|c|c|c|c|}
\hline Year & ROE (X1) & $\begin{array}{c}\text { Expected market return, } \\
\text { smoothed (X2) }\end{array}$ & $\begin{array}{c}\text { Shadow economy, percent of } \\
\text { GDP (Y)* }\end{array}$ & $\begin{array}{c}\text { Shadow economy, percent of } \\
\text { GDP, estimated (Ye) }\end{array}$ \\
\hline 2010 & 1.0 & 32.8 & 38 & 35 \\
\hline 2011 & 4.5 & 27.6 & 34 & 34 \\
\hline 2012 & 2.0 & 19.4 & 34 & 34 \\
\hline 2013 & -1.2 & 16.4 & 35 & 44 \\
\hline 2014 & -36.1 & 20.0 & 43 & 40 \\
\hline 2015 & -18.2 & 43.1 & 40 & 35 \\
\hline 2016 & 1.2 & 50.7 & 35 & 33 \\
\hline 2017 & 7.0 & 52.8 & 32 & 32 \\
\hline 2018 & 11.2 & 34.5 & 30 & \\
\hline
\end{tabular}

Source: calculations of the Ministry of Economic Development of Ukraine, 2019

on invested capital and the size of the total shadow sector will be.

Processing the relevant data results into the following two-factor regression equation, which enables to find the estimated values ( $\mathrm{Ye}$ ) of the shadow economy:

$$
\mathrm{Ye}=34,7-0,25355 \mathrm{X} 1+0,004919 \mathrm{X} 2
$$

Regression model 2 confirms that ROE and the shadow economy are negatively correlated while the risks of investing in equity, reflected in the expected return on equity, and the total shadow income correlate positively. This linear multiple regression is adequate to the initial data, which is confirmed by the similar dynamics of the given and estimated levels of the shadow economy. This is evident in the diagram (Figure 1). In addition, the results of comparing the actual and the table value of the Fisher coefficient confirm the adequacy of the model. Significant excess of $\mathrm{F}_{\text {actual }}$ (18.04) over $\mathrm{F}_{\text {table }}$ (2.36) indicates the statistical significance of the model.

We prove the significant influence of the factors of return on equity and expected rate of return on the total size of the shadow economy, the main component of which is the shadow (undeclared) income of enterprises. Therefore, this approach should be applied to calculate the shadow interest rate on equity as the difference between the expected return on modified CAPM and the official ROE. The estimated absolute amount of the shadow income of enterprises is found by applying the shadow interest rate to the average annual amount of equity of enterprises. Table 3 shows the results of calculating the value of undeclared income based on the shadow rate of cost of equity.

The data in Table 3 enable to construct a linear regression that describes the dependence of the shadow income of enterprises on the size of official ROE and expected market profitability:

$$
\mathrm{Ye}=8,68-1,03741 \mathrm{X} 1+0,7683 \mathrm{X} 2
$$

Regression model 3 confirms that, similarly to the case of the total shadow economy, the ROE correlates negatively with the level of the corporate shadow income, while the expected rate of return on equity

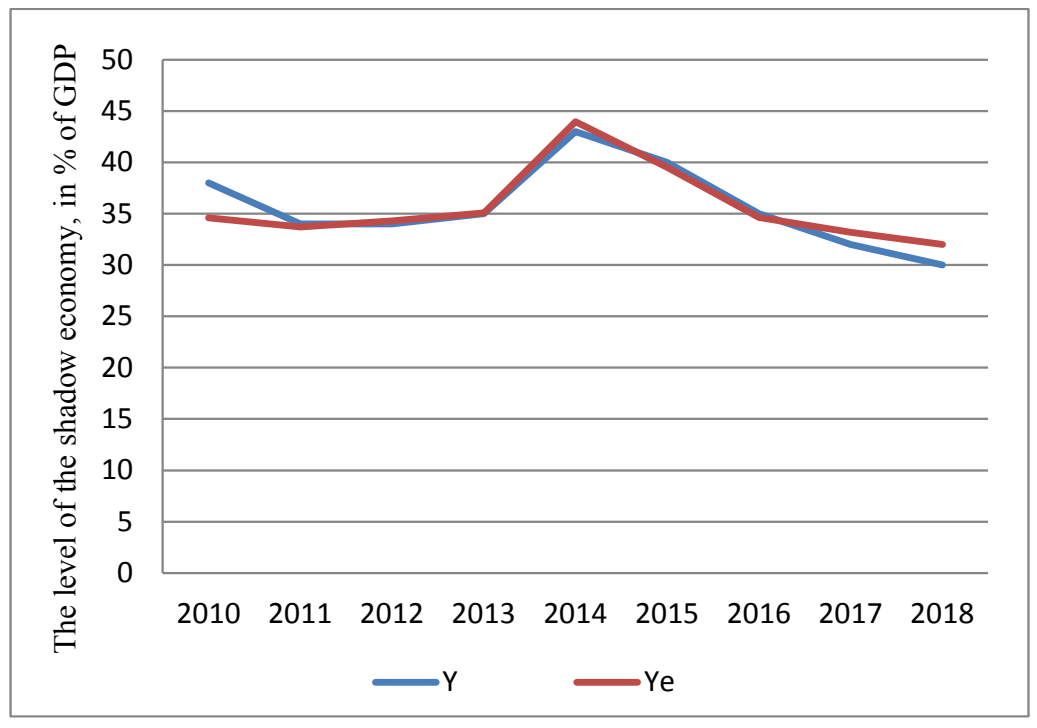

Figure 1. Dynamics of given and estimated levels of the shadow economy of Ukraine 
Table 3

Calculation of the shadow income of enterprises in Ukraine based on the shadow cost of equity, 2010-2018

\begin{tabular}{|c|c|c|c|c|c|c|c|c|}
\hline Year & ROE (X1) & $\begin{array}{c}\text { Expected } \\
\text { market return, } \\
\text { smoothed }(\mathrm{X} 2)\end{array}$ & $\begin{array}{c}\text { Shadow cost of } \\
\text { equity, } \%\end{array}$ & $\begin{array}{l}\text { Equity, } \\
\text { bln. UAH }\end{array}$ & $\begin{array}{l}\text { Shadow } \\
\text { income, } \\
\text { bln. UAH }\end{array}$ & $\begin{array}{c}\text { GDP, } \\
\text { bln. UAH }\end{array}$ & $\begin{array}{l}\text { Shadow income, } \\
\text { percent of GDP } \\
(\mathrm{Y})\end{array}$ & $\begin{array}{l}\text { Shadow income, } \\
\text { percent of GDP, } \\
\text { estimated (Ye) }\end{array}$ \\
\hline 2010 & 1.0 & 32.8 & 31.8 & 1339 & 425.8 & 1079.3 & 39 & 33 \\
\hline 2011 & 4.5 & 27.6 & 23.1 & 1510 & 348.8 & 1299.9 & 27 & 25 \\
\hline 2012 & 2.0 & 19.4 & 17.4 & 1780 & 309.7 & 1404.7 & 22 & 22 \\
\hline 2013 & -1.2 & 16.4 & 17.6 & 1932 & 340.0 & 1465.2 & 23 & 22 \\
\hline 2014 & -36.1 & 20.0 & 56.1 & 1633 & 916.1 & 1586.9 & 58 & 62 \\
\hline 2015 & -18.2 & 43.1 & 61.3 & 2049 & 1256.0 & 1988.5 & 63 & 61 \\
\hline 2016 & 1.2 & 50.7 & 49.5 & 2396 & 1186.0 & 2383.2 & 50 & 46 \\
\hline 2017 & 7.0 & 52.8 & 45.8 & 2423 & 1109.7 & 2982.9 & 37 & 42 \\
\hline 2018 & 11.2 & 34.5 & 23.3 & 2564 & 597.4 & 3558.7 & 17 & 24 \\
\hline
\end{tabular}

correlates positively with the value of undeclared incomes. This linear multiple regression is adequate to the initial data, which is confirmed by the dynamics of the specified and estimated levels of shadow income (Figure 2). Comparison of the actual and table value of the Fisher coefficient $\left(F_{\text {actual }}=41,86 ; F_{\text {table }}=2,36\right)$ shows the high statistical significance of the model.

Before interpreting the results of the shadow economy analysis using the hidden cost of equity method, it should be emphasized that undeclared business income is just one (albeit the largest) component of the shadow economy, along with undeclared wages and hidden employment income. Applying the approach of T. Putnins and A. Sauka (2015), the Kyiv International Institute of Sociology (KIIS), based on surveys of 800 executives and top managers of companies, estimated the shadow economy of Ukraine in 20172018. The level of the shadow economy in 2018 made up $47.2 \%$ of total GDP and $46.8 \%$ in 2017 . The largest share of the shadow economy is hidden business income (about 57-60\%) (The results of the study under the project SHADOW H2020, 2019). The rest is the concealment of employee income (the income of unregistered workers and undeclared wages). According to this approach, the shadow income of enterprises is about a quarter of GDP (2018).

Therefore, the range of estimates of the shadoweconomy level in Ukraine, depending on the chosen method of determination, is quite varied: from $47 \%$ (Zbruch, 2015) to $23.8 \%$ of GDP (National Bank of Ukraine, 2020). Our estimates of 2018 are near the lower limit of the range. In general, compared to alternative calculations, for example the Ministry of Economic Development, the proposed method is more sensitive to risks, as well as to decisions aimed at improving business conditions. Evidently, the exacerbation of risks automatically reflects on the expectations about the return on investment and the official declaration of income.

Table 3 shows that, over the years of relatively stable economic conditions, shadow income estimates are approximately the same according to both the shadow return method and alternative approaches. In times of crisis (2014-2016) and increased risks, an abnormally high level of shadowing occurs. At first glance, the figures of this period are too high. However, the analysis of the enterprises' official reporting data, as well as the level

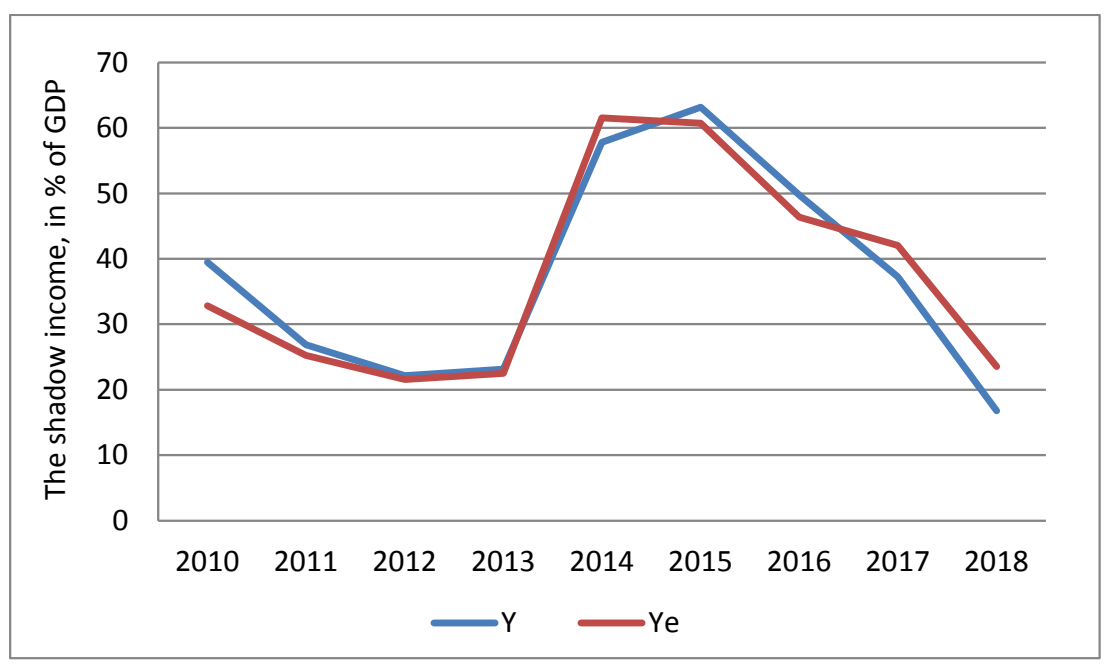

Figure 2. Dynamics of the given and estimated level of shadow income of enterprises 
of inflation, sovereign ratings of the country and GDP collapse, reveals that the estimates of income shadowing are the most realistic. Other methods of valuation are not so risk-sensitive, and therefore, demonstrate a more optimistic picture.

For most businesses, income shadowing is a major offset for increased risks and a way of ensuring a high expected return on investment. For example, costs of equity of the average Ukrainian enterprise is $2-2.5$ times higher than the corresponding indicator of enterprises operating in developed markets. The main sources of profit (high risk premium) for owners (investors) are:

- high prices for products (services);

- staff cost savings (low salaries and unofficial salaries);

- counterfeiting and use of low-quality materials, products, services;

- savings from the use of different tax evasion schemes;

- other sources, such as low recourse usage fees, low rental costs, and more.

Table 4 summarizes the results of the survey on sources of profit (high risk premium) for owners (investors) in Ukraine as of 2018. The results of the study revealed that the most significant sources of ensuring an additional risk premium for investing in Ukraine are low staff costs and savings from tax evasion schemes. Tax evasion is a source of offsetting additional risks for $75 \%$ of large and $95 \%$ of small and medium-sized enterprises.

Staff cost savings are the main source of generating added costs for owners of $90 \%$ of large and $85 \%$ of the Ukrainian SMEs that participated in the survey. High costs of equity, in particular, their shadow component is one of the reasons for low wages in Ukraine and their shadowing. According to KIIS survey, 32\% of company employees in 2018 were not formally employed, $45 \%$ were paid informally (The results of the study under the project SHADOW H2020, 2019). Such results correlate with the results of empirical analysis, which have revealed no significant relationship between the country's level of risk (in emerging markets) and unemployment (Tereshchenko, 2017). This means that one of additional risks offsets is the wage shadowing. In addition, low wages counterbalances substantially the effect of dismissal of employees due to rising risks. As a result, in Ukraine, the share of wage costs in the cost structure and in relation to GDP is substantially lower than in developed countries.

The study of the causality of risks, the cost of attracting capital and the size of income shadowing, implies that in order to minimize the shadow economy the risks of enterprise activity, especially macroeconomic, corruption, criminal risks and risks of low property protection should be reduced.

\section{Conclusion}

Empirical data confirm that the higher the local risks, the greater the size of the shadow economy, and concealment of income relatively. In times of crisis and recession, an increase in shadow activity occurs. In the presence of causal relations between the shadow activity of enterprises and the cost of equity, the latter should be considered as a variable to calculate the amount of undeclared income of enterprises as the largest segment of the shadow economy.

Given the high risks of doing business on EM, particularly in Ukraine, investors (owners) expect an excessively high risk premium. For super profit, businesses in such countries use minimizing staff costs, tax evasion, reducing the quality of finished goods (services), or counterfeit goods. Most of cost of investing capital in these countries flows into the shadow sector. Therefore, a vicious circle occur: high risks force companies to use shadow schemes and sources of payment of an additional risk premium to investors; on

Table 4

Sources of additional risk premium for investing in an enterprise's equity, an example of Ukraine (data from Tereshenko, Voloshanyk \& Savchuk, 2019)

\begin{tabular}{|c|c|c|c|c|}
\hline \multirow[t]{2}{*}{ Characteristics } & \multicolumn{2}{|c|}{ Large enterprises } & \multicolumn{2}{|c|}{$\begin{array}{c}\text { Small and medium-sized } \\
\text { enterprises }\end{array}$} \\
\hline & Amount & $\%$ & Amount & $\%$ \\
\hline Total enterprises surveyed & 20 & 100 & 20 & 100 \\
\hline Enterprises that have paid official dividends over the past five years & 3 & 15 & 1 & 5 \\
\hline Enterprises that have paid income to owners over the past five years & 20 & 100 & 20 & 100 \\
\hline $\begin{array}{l}\text { Sources of additional risk premium compensation - high prices for } \\
\text { products (services): } \\
\text { - staff cost savings (low salaries and unofficial salaries); } \\
\text { - counterfeiting and use of low-quality materials, products, services; } \\
\text { - revenue shading savings; } \\
\text { - other sources. }\end{array}$ & $\begin{array}{c}5 \\
18 \\
6 \\
15 \\
8\end{array}$ & $\begin{array}{l}25 \\
90 \\
30 \\
75 \\
40\end{array}$ & $\begin{array}{c}1 \\
17 \\
15 \\
19 \\
5\end{array}$ & $\begin{array}{l}5 \\
85 \\
75 \\
95 \\
25\end{array}$ \\
\hline $\begin{array}{l}\text { Shadow schemes of income payments to owners (investors): } \\
\text { - moving profits to tax havens (offshore zones); } \\
\text { - fictious expenses through missing trader; } \\
\text { - manipulation of the tax benefits; } \\
\text { - payment of inflated royalties, interest, commissions, agency fees, etc. }\end{array}$ & $\begin{array}{l}9 \\
8 \\
6 \\
4\end{array}$ & $\begin{array}{l}45 \\
40 \\
30 \\
20\end{array}$ & $\begin{array}{c}3 \\
15 \\
7 \\
2\end{array}$ & $\begin{array}{l}15 \\
75 \\
35 \\
10\end{array}$ \\
\hline
\end{tabular}


the other hand, the shadow economy is a risk factor of an inflated premium.

The key parameters of a calculation model for the expected cost of equity capital throughout the entire corporate sector in countries related to EM are substantiated: risk-free rate of return, global market risk premium, country risk premium. The beta factor is omitted in the model because it is aimed at calculating the average market rate of return. The estimation of the shadow income of enterprises requires utilisation of the smoothed values of the expected risk premium. This is due to the fact that some enterprises respond to risk factors in the period of their manifestation, the other act outstripping, and some entities need time to understand the risk factors and develop income shadowing schemes.

The shadow economy component, formed by shadowing the income of enterprises, is proposed to determine according to the rate of the shadow cost of equity. The latter is calculated as the difference between the expected market rate of cost of equity and the return on equity invested, determined on the basis of official reporting indicators. The approximate value of the absolute amount of the shadowed income is derived from the application of the shadow rate of cost of equity to the value of the assets of enterprises financed by equity.

The regression-correlation analysis confirms the presence of a negative correlation between the ROE and the level of the shadow economy. The risks of investing in equity, reflected in the expected return on equity, and the total shadow income correlate positively. The analysis of the dependence of the shadow income of enterprises on these factors confirms a similar pattern.

Comparison of the obtained values of the shadow income of enterprises in Ukraine with alternative estimates of the shadow economy reveals a higher sensitivity of the proposed method to changes in country risks, as well as to decisions aimed at improving business conditions.

For example, the abnormally high values of the shadowing of corporate income in 2014-2015 is the result of a sharp downgrades of the country's credit and investment ratings, extremely high inflation and other threats. Obviously, under such conditions, most of the business has transformed its incomes into the shadow. This was reflected in both the sharp decline in official GDP and the negative values of financial results. Since 2017, the size of shadow incomes has been decreasing sharply, as a result of an improvement in the ease of doing business index in Ukraine, a decrease in inflation and a gradual decrease in the risk premium. The consequence is an increase in official incomes of enterprises and GDP of the country. It is confirmed that the exacerbation of risks automatically reflects on the expectations regarding the return on investment and on the official declaration of income. Therefore, the shadow economy reduction is related directly to a set of measures aimed at minimizing the risks of business activities.

\section{References:}

Gardner, M., Wamhoff, S., Martellotta, M., \& Roque, L. (2019). Corporate Tax Avoidance Remains Rampant under New Tax Law. Institute on Taxation and Economic Policy (ITEP). Retrieved from: https://itep.org/wp-content/ uploads/04119-Corporate-Tax-Avoidance-Remains-Rampant-Under-New-Tax-Law_ITEP.pdf

Oxfam Deutschland e.V. (2019). Retrieved from: https://www.oxfam.de/

Stiglitz, J. E., \& Pieth, M. (2016). Overcoming the Shadow Economy. Series: International Policy Analysis. Published by Friedrich Elbert Stiftung.

Schneider, F. und Boockmann, B. (2018). Die Größe der Schattenwirtschaft - Methodik und Berechnungen für das Jahr 2018. Linz; Tübingen. Retrieved from: http://www.iaw.edu/index.php/-288/member/222

Putnins, T., \& Sauka, A. (2015). Measuring the shadow economy using company managers. Journal of Comparative Economics, vol. 43, issue 2, pp. 471-490.

Medina, L., \& Schneider, F. (2018). Shadow Economies Around the World: What Did We Learn Over the Last 20 Years? IMF Working Paper, WP/18/17. Retrieved from: https://papers.ssrn.com/sol3/papers.cfm?abstract_id=3124402

Breusch, T. (2005). Estimating the underground economy using MIMIC models. Working Paper 2005, Canberra, Australia. Retrieved from: http://econwpa.wustl.edu/eps/em/papers/0507/0507003.pdf

Copeland, T., Koller, T. and Murrin, J. (2000). Valuation-Measuring and Managing the Values of Companies. John Wiley Sons, New York.

Tereshenko, O., Voloshanyk, N., \& Savchuk, D. (2019). Rate of Cost on Investment Capital in Emerging Markets. Sosiety, Integration, Education. Proceedings of the International Scientific Conference. Rezekne. Volume 6, pp. 665-674.

Shadow economy in Ukraine. Results of researh of 2019 in the framework of the project SHADOW H2020. Retrieved from: http://kiis.com.ua/materials/pr/20191107_Shadow/Shadow_UA.pdf

Combined method of E\&Y, Mastercard. Research of shadow economy in Ukraine. Retrieved from: https://bank.gov.ua/news

Tereshchenko, O., \& Voloshanyuk, N. (2017). Capital implicit expenses in the shadow economic revenue. PNAP, no 6, pp. 85-94.

Zbruch (2015). The level of the shadow economy has grown to 47\%. Retrieved from: https://zbruc.eu/ node $/ 40301$ ? theme $=$ zbruc $\&$ page $=211$ 